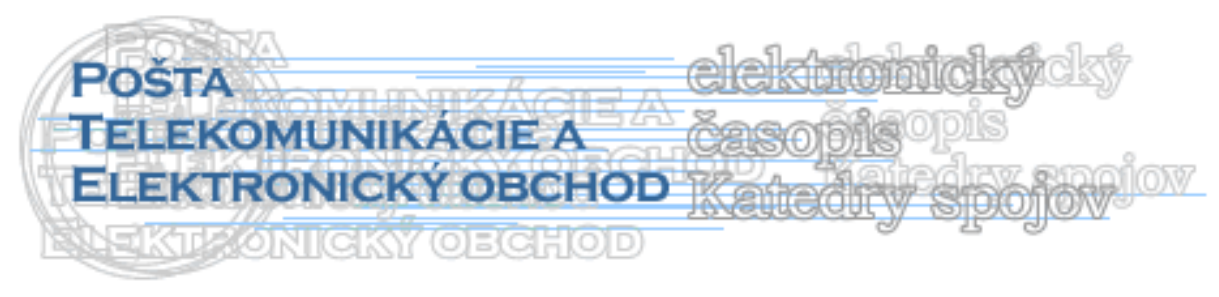

\title{
RIADENIE KONFLIKTOV V PODNIKU
}

\author{
Jaroslava Kádárová - Marek Vida - Gabriel Kádár*
}

\section{Úvod}

V podnikoch sa konflikty vyskytujú odjakživa, pretože v živote spoločenstiev sa im nedá vyhnút'. Konflikty na pracoviskách sú špecifické tým, že vznikajú medzi l'ud'mi, ktorí vzájomne spolupracujú pri plnení rozličných úloh v rámci podniku. Vyskytujú sa tak vo vonkajšej podobe (napr. štrajk), ako aj vo formách a prejavoch menej viditel'ných (napr. pasívna rezistencia založená na ignorovaní pokynov vedenia alebo na nedbanlivom či spomalenom plnení pracovných príkazov, čo negatívne pôsobí na fungovanie podniku a spôsobuje napätie vo vzt’ahoch medzi pracovníkmi). Pritom je známe, že medzil'udské vzt’ahy v podnikoch predstavujú významný faktor spokojnosti l’udí so zamestnaním.

\section{Príčiny vzniku konfliktov na pracovisku}

Konfliktom je každý hodnotový, názorový rozpor, stret protichodných tendencií, alebo motívov, snáh dvoch, alebo viacerých strán. Podla Ralpha Dahrendorfa [3] má konflikt spoločenský charakter vtedy, ked' pramení z určitej spoločenskej štruktúry, má nadindividuálny charakter a ked’ sa na ňom zúčastňujú rozličné kvázi skupiny. Problémom zo sociologického hl'adiska je spôsob riešenia konfliktu.

Zdrojom konfliktov na pracoviskách môže byt' snaha zamestnancov získat' čo najlepšie platové podmienky, ale môže to byt' aj diferencovanost' ich postojov, kultúry, získaného vzdelania či výchovy. Väčšina konfliktov má svoj pôvod v nasledujúcich zdrojoch:

- Odlišné vnímanie - ak obe zúčastnené strany sa na tú istú vec pozerajú z rôznych aspektov, majú rozdielny názor na tú istú vec, jedna strana vyzdvihuje len pozitíva a druhá vidí len negatíva.

- Odlišné hodnoty - ak obe zúčastnené strany majú odlišné presvedčenie.

- Rôzne záujmy - sa vyskytujú, ked' l’udia uprednostňujú rozdielne záujmy, akcie, veci.

- Limitované zdroje - nepresne sa vymedzí, kto a čo chce a potrebuje.

- Psychologické potreby - každý človek má potrebu, aby ho iní videli v priaznivom svetle, ako schopného, zodpovedného, úspešného.

\footnotetext{
* Ing. Jaroslava Kádárová, PhD., Ing. Marek Vida, Ing. Gabriel Kádár, Technická univerzita v Košiciach, Strojnícka fakulta, Katedra manažmentu a ekonomiky, Němcovej 32, 04200 Košice, tel.: +421556023242, fax: +421556023233, e-mail: Jaroslava.Vidova@tuke.sk
} 
Často je t’ažké odhalit' príčiny konfliktov, no najčastejšími dôvodmi konfliktov sú:

- Komunikačné dôvody konfliktov sú najzávažnejšie a zároveň najfrekventovanejšie. Pod zlou komunikáciou je možné chápat' nedostatočné počúvanie toho druhého, nedostatočné zdiel'anie informácií, rozdiely medzi interpretáciou a vnímaním informácie a ignorovanie neverbálnej komunikácie.

- Štrukturálne dôvody konfliktov spočívajú zväčša vo vel'kosti podniku alebo tímu, dížke obratu informácií, zainteresovanosti jednotlivých členov podniku, systému finančného ohodnocovania a v množstve závislostí medzi členmi tímu.

- Personálne dôvody konfliktov zahŕňajú veci ako sebaúctu, osobné ciele jednotlivcov, ich hodnoty a potreby. K úspešnému zdolaniu konfliktu je potrebné, aby si manažéri a členovia tímu uvedomovali nepredvídatel'nost' týchto potrieb, ich dopad na jednotlivcov a na tím ako taký.

\section{Typy konfliktných situácií}

Účinok konfliktov na podnik je spravidla destabilizačný, pretože odčerpávajú energiu, ktorá by sa mala vynakladat' na plnenie štatutárnych úloh a ciel'ov podniku. Konflikt je konštruktívny $\mathrm{v}$ prípade, že by sa do riešenia určitého problému zapoja viaceré osoby $\mathrm{s}$ rozličnými názormi a prístupmi. V takomto prípade účastníci konfliktu predkladajú svoje diferencované, no pre riešenie veci prínosné argumenty. Podl'a dopadu na pracovníka a plnenie úloh sa konflikty všeobecne rozdel'ujú do dvoch skupín [2]:

- Mobilizujúce konflikty sú také, ktoré majú na pracovisku pozitívny vplyv, lebo vedú k rozvoju činnosti a jej skvalitneniu. Väčšinou ide o presadzovanie nových pracovných metód, reorganizáciu pracoviska, alebo výber nových materiálových zdrojov, dodávatel'ov alebo odberatel'ov.

Rôzne pracovné skupiny môžu mat' rôzne hl'adiská a tie sa riešia niekedy vel'mi rušným jednaním. Ich pozitívne vyriešenie záleží na schopnostiach manažéra, jeho rozhl'ade, odborných znalostiach, vplyve na spolupracovníkov a všeobecnej dôvere i autorite. Manažér musí byt' na riešenie konfliktu dôkladne pripravený, a to vedením predchádzajúcich porád so svojimi kompetentnými spolupracovníkmi. Riešenie konfliktu musí prebiehat' pokojne, vecne, bez osobných invektív a emócií.

Charakteristikou mobilizujúcich konfliktov je ich krátkodobost'. Problém je nutné vyriešit' pokial' možno čo najskôr. V záverečnom riešení by mali byt' aspoň čiastočne zohl'adnené jednotlivé názory opozičných strán, žiadna zo zúčastnených strán by nemala odchádzat' $\mathrm{z}$ jednania s pocitom porážky alebo zlého konečného riešenia.

- Deštruktívne konflikty sú negatívnym prejavom či už jednotlivca, manažmentu alebo celého pracoviska. Aj mobilizujúci konflikt prerastá do deštruktívneho konfliktu, ak nie je včas a hlavne úspešne vyriešený. Kazí sociálnu klímu nevedie k riešeniu problémov a často je len dôsledkom osobných hádok jednotlivých osôb, alebo pracovných skupín. Taký spôsob komunikácie často nerešpektuje žiadne pravidlá, všetko je dobré $\mathrm{k}$ pokoreniu druhého a domnelej výhre. Úlohou manažmentu je čo najrýchlejšie vyriešit' takéto konflikty použitím všetkých dostupných právomocí, aj za cenu dočasnej nevýhodnosti pre činnost' pracoviska. 
Dlhodobé konflikty sú neproduktívne, sú ukazovatel'om nezdravých pomerov na pracovisku, nutne vedú $\mathrm{k}$ zhoršeniu medzil'udských vzt’ahov a klímy na pracovisku. Dlhodobé konflikty sú súčasne dôkazom zlého manažmentu, ktorý ich nedokáže včas riešit', čo je jedným z jeho základných úloh.

Je pochopitel'né, že deštruktívne konflikty sa riešia ovel'a t'ažšie ako vecné mobilizujúce konflikty, už tým, že ich vyvolávajú nezdravé pomery na pracovisku a často aj negatívne perspektívy. Predovšetkým ide o pracovnú nespokojnost' zamestnancov, ich sociálnu neistotu, negatívne charakterové i odborné vlastnosti manažmentu, zlé medzil'udské vzt'ahy a hlavne pocit nespravodlivosti, či už v posudzovaní odborných kvalít a zásluh, ako aj ich ohodnocovaní.

\section{3 Úloha manažmentu pri riešení konfliktov}

Úlohou manažmentu je predovšetkým prevencia konfliktných zdrojov a situácií. Úplne sa však nedá konfliktom vyhnút'. Na riešenie konfliktných situácií a riešenie už prebiehajúcich deštruktívnych konfliktov existuje niekol'ko doporučení a prístupov, ktorých výber je jedným z dôležitých hodnotiacich faktorov kvalít manažéra. Medzi dôležité opatrenia patrí predovšetkým preventívne rozmiestnenie pracovníkov nielen podl'a ich odborných, ale aj charakterových a psychologických vlastností, ich dodatočné premiestňovanie a eliminácia konfliktných jednotlivcov a skupín. Ďalej je to vytváranie vyvážených pracovných skupín, tímov, vedených k orientácii na spolupatričnost' ku skupine, k lojalite k podniku a záujmu o jeho ekonomické výsledky a celkovú prosperitu, na identifikáciu sa s ňou. Ťažké je riešenie tejto problematiky tam, kde zdrojom konfliktov je sám nadriadený, ktorý môže konflikty vyvolávat' svojou prílišnou direktívnost'ou až diktátorstvom, zlými osobnými vlastnost’ami i neodbornost'ou, nespravodlivým hodnotením jednotlivcov a pracovných skupín.

K základným charakteristikám konfliktnej osobnosti patria predovšetkým:

- labilnost', náladovost' a vzt'ahovačnost',

- agresívnost', dominantnost' a egocentrickost',

- nevyrovnanost' a psychopatickost'. [2]

Riadený konflikt je užitočný pre podnik, lebo poskytuje priestor na výmenu názorov na rôzne prístupy a ponúka variantné riešenia. Riadené konflikty umožňujú, aby sa podnik d’alej rozvíjal.

Konflikt na pracovisku nie je obvykle ničím príjemným. Aj po vyriešení zanecháva $\mathrm{v}$ účastníkoch napätú situáciu. Ak sa naopak konflikt začne a adekvátnym spôsobom nedorieši, preukázatel'ne blokuje pracovnú pozornost', a tým aj výkon jeho bezprostredných nositel'ov. Každý pracovník, ktorý sa dostáva do konfliktu pocit’uje istú mieru frustrácie, ktorá sa zvyšuje, ak konflikt nie je riadený a trvá príliš dlhé obdobie. Preto je potrebné predchádzat' zbytočným konfliktom a vzniknuté konflikty konštruktívne riešit'.

\section{Stratégie riešenia konfliktov}

Pri riešení konfliktov je možné využit’ rôzne stratégie. Pre úspešné zvládnutie konfliktu je potrebné poznat' výhody a nevýhody jednotlivých stratégii pre riešenie konfliktov, poznat' situáciu, závažnost' problému, vyspelost' zúčastnených strán na konflikte, úroveň vzt'ahov 
zúčastnených strán a podobne. K základným stratégiám riešenia konfliktov je možné zaradit' nasledujúce stratégie:

- Stratégia konfrontácie predstavuje spôsob riešenia konfliktov, ked' jedna zo zainteresovaných strán pristupuje $\mathrm{k}$ dosiahnutiu svojich ciel'ov bez ohl'adu na dôsledky, ktoré to môže mat' na ostatných. Táto stratégia patrí k typu „,ýhra prehra“.

Obvykle sa využíva v situácii, ked' jedna zo strán môže využit' silu formálnej autority (napr. nadriadené postavenie manažéra a $\mathrm{z}$ toho vyplývajúce právomoci), ked' niektorá zo strán kontroluje zdroje, ktoré druhá strana nevyhnutne potrebuje, pod vplyvom prostej fyzickej hrozby či arogantného ignorovania požiadaviek protistrany.

Negatívom konfrontačného prístupu k eliminácii konfliktu je, že vedie k vzniku pocitov nepriatel'stva a túžby po odplate. Z krátkodobého hl'adiska je účinok rázneho zásahu skutočne efektívny. Pri dlhodobej preferencii takéhoto prístupu vzrastá skrytý odpor, napätie, zníženie ochoty akceptovat' príkazy a znášat' nepriaznivé emocionálne nároky.

- Stratégia vyhladzovania konfliktov a ústupu je opačnou stratégiou k stratégii konfrontácie. Dôraz je kladený na zachovanie priatel'ských vzt’ahov, čo je na úkor kritického zhodnotenia situácie a jej reálneho riešenia. Ústup znamená uspokojenie oponenta $\mathrm{v}$ čo možno najvyššej miere tým, že jeho záujmy sa nadradia nad osobné. Kvôli zachovaniu pokoja je jedna zo strán ochotná priniest' obete.

Takýto prístup často uprednostňujú manažéri, ktorí sú zástancami vyslovene „mäkkého“ štýlu riadenia a necítia sa dostatočne kompetentní, aby využili svoju formálnu autoritu. Spravidla sa obávajú negatívnych emócií a prípadného stresu vyvolaného stretnutím sa s opozičnými stranami konfliktu. Preto sa konfliktné strany usilujú upokojovat', zmierňovat', resp. „presvedčit““ jednu zo strán konfliktu, aby dobrovol'ne ustúpila. Konflikty tak ustupujú do latentnej fázy. Je však len otázkou času, kedy opätovne a často ešte vo väčšej sile vystúpia na povrch.

- Stratégia vyhýbania sa konfliktom predstavuje prístup, ktorý nerešpektuje záujmy podniku ani záujmy druhých. Dominujú tu v podstate egoistické záujmy nekompetentného manažéra, ktorý mená záujem alebo nedokáže konflikty riešit'. Túto stratégiu uprednostňujú často manažéri, ktorí nie sú emocionálne ani osobnostne pripravení vyrovnávat' sa s medzil'udsky náročnými konfliktnými situáciami. Preto sa usilujú upokojovat', bagatelizovat' význam problémových situácií. Opakované využívanie tejto stratégie spôsobuje hromadenie problémov, čo spôsobuje silnú frustráciu podriadených.

- Stratégia kompromisu sa uplatňuje v situáciách, ak sa obidve strany konfliktu vzdávajú časti svojich nárokov $v$ prospech dohody. Predmet sporu sa rozdelí medzi obe strany a jeden ústupok sa vyváži druhým. Princípom takéhoto riešenia konfliktu je obetovanie niečoho v prospech spoločného ciel’a alebo záujmu.

- Stratégia využitia skúseností overených vpraxi je stratégia riešenia konfliktov, ktorá v sebe skrýva nebezpečenstvo. Kompromis totiž iba otupuje ostrie konfliktu, ktorý má tendenciu opät’ sa oživovat' a obvykle vedie zúčastnené strany k tomu, aby si $\mathbf{v}$ záujme zmieru vydobýjali od vedenia podniku čoraz nerealistickejšie požiadavky či ústupky. 
- Stratégia kooperácie sa uplatňuje v situáciách, ked' všetky zúčastnené strany berú ohl'ad na záujmy druhých a pracujú spoločne na vzájomne výhodnom riešení. $\mathrm{V}$ centre pozornosti je riešenie, ktoré uspokojí obidve strany. [1]

- Stratégia argumentácie je taký spôsob ovplyvňovania druhých l'udí, ktorý sa zakladá na ich vzájomnom verbálnom aj neverbálnom pôsobení. Jeho účinnost' závisí od:

- osobnostných charakteristík človeka, ktorý presviedča,

- osobnostných charakteristík človeka, ktorý je presviedčaný,

- kontextu situácie.

Z hl'adiska účinných praktík presviedčania sa zvyčajne uvádzajú tri základné prístupy $\mathrm{k}$ presviedčaniu:

- presviedčanie prostredníctvom dôveryhodnosti,

- presviedčanie prostredníctvom logického zdôvodňovania,

- presviedčanie prostredníctvom emocionálnych apelov.

Presviedčanie druhých má väčšiu nádej na požadovaný účinok vtedy, ak sa tieto prístupy vhodne kombinujú. Schopnost' ústne presviedčat' sa uplatňuje nielen $\mathrm{v}$ bežnom sociálnom styku, ale najmä v zložitejších sociálnych situáciách, ked' treba v diskusii objasnit' a obhájit' svoje stanoviská.

Umenie argumentácie nespočíva len v obhajobe vlastných názorov, ale aj v schopnosti klást' správne otázky druhej strane. Odpovede na položené otázky majú umožnit' čo najlepšie pochopit' názorovú pozíciu druhej strany, objasnit' jej potreby a vzt’ah k argumentujúcemu jeho predstavám, záujmom a potrebám. Pri formulovaní otázok je užitočné držat' sa nasledujúcich rád:

- neklást' otázky len preto, aby boli položené,

- preferovat' otvorené otázky,

- pýtat' sa aj na názor partnera,

- pýtanému dožičit' čas na rozmyslenie,

- osobné otázky klást' uvážene.

Pozorné aktívne počúvanie však samo osebe nepostačuje. Na to, aby sa obe strany dohovorili, sa musia navzájom presvedčit' o prednostiach či výhodách ponúkaných riešení alebo prínosu, ktorý so sebou nesie obojstranne prijatel'ná dohoda. Pri diskusii by mal každý z partnerov nájst' vhodné argumenty objasňujúce vlastné stanoviská, primeraným spôsobom zist'ovat' stanoviská partnera a dospiet' $\mathrm{k}$ obojstranne prijatel'nému riešeniu. Skutočné počúvanie je vysoko aktívna činnost', ktorá zahíňa:

- schopnost' porozumiet' tomu, čo sa povedalo,

- schopnost' triedit' a analyzovat' povedané tak, aby to bolo možné zachovat' pre nasledujúce použitie,

- vysielanie informácií hovoriacemu mimikou, gestami aj slovne, prostredníctvom ktorých mu signalizujete, že počúvate.

Aktívne počúvat' teda znamená venovat' hovoriacemu dostatočnú pozornost', udržiavat's ním primeraný očný kontakt, prejavovat' oňho a o jeho informácie záujem, z času na čas prikývnut', klást' mu objasňujúce otázky, parafrázovat' a zhŕňat' jeho myšlienky.

Hlavné chyby pri aktívnom počúvaní druhých sú [7]:

- L’udia sa zvyčajne dokážu len zriedka sústredit' dlhší čas. 
- Pri počúvaní iných bývajú roztržití, všeličo prepočujú fakticky alebo z emocionálnych

- dôvodov.

- Nepočujú to, čo ich nezaujíma, alebo to, čo im je nepríjemné.

- Menej počúvajú l’udí, ktorí sú im nesympatickí.

- Mnohí sú dokonca natol'ko zaujatí vlastnou osobou a tým, čo chcú v rozhovore povedat',

- Že počúvanie je netrpezlivým čakaním na to, kedy sa konečne dostanú k slovu oni sami.

- Názorová nezhoda.

- Súperenie o nejakú výhodu, spor o svoju pravdu alebo iná konfliktná situácia.

\section{Záver}

Konflikty na pracovisku je vhodné využívat' na konštruktívne zmeny, aj ked' väčšina l'udí pristupuje ku konfliktom, ako k niečomu zlému. Mnohí sa snažia predíst' konfliktom pasívnym prístupom k ním, čo považujú za spôsob ako predíst' konfliktu. Často potom dochádza $\mathrm{k}$ tomu, že konflikt sa vráti neskôr, ked’že stále čaká na svoje vyriešenie. Vel'a konfliktov napomáha vidiet' čo nefunguje dobre v podniku a čo je potrebné urobit'. V konfliktoch je vel'mi vel'a pozitívnej aj negatívnej energie, ktorú by mali manažéri vhodne využívat' pre prospech podniku ako celku a jeho jednotlivých pracovníkov.

\section{Literatúra}

1. Ako si poradit's konfliktami na pracovisku. In: eFocus, roč. 8, č. 3/08, s. 64. ISSN 1336-1805.

2. BOHUMEL A.: Konflikty na pracovisku. http://www.eprogress.sk/post/konflikty-napracovisku-138

3. MIHOK, J. - NAŠČĆKOVÁ, J. - MALEGA, P.: Mobbing ako jeden z faktorov negatívne ovplyvňujúci výkonnost' na pracovisku. In: Manažment l'udského potenciálu $\mathrm{v}$ podniku : Zborník referátov medzinárodnej vedeckej konferencie, Zvolen, 17.-18. mája 2006. Zvolen : TU, 2006. s. 45-49. ISBN 80-228-1585-3.

4. MIHOK, J. - VIDOVÁ, J.: Metódy riešenia krízových situácii v podniku.. In: Manažment priemyselných podnikov, roč. III., č. 3/2006, Zvolen 2006, s. 58-63. ISSN 1336-5592.

5. MIHOK, J. - VIDOVÁ, J.: Riadenie krízy na pracovisku. In: Medzinárodná vedecká konferencia „Manažment l'udského potenciálu v podniku“, KPH Drevárska fakulta TU Zvolen, Zvolen 2006, ISBN 80-228-1585-3, s. 125-130.

6. MIHOK, J. - VIDOVÁ, J.: Riadenie podniku v kríze. SjF TU v Košiciach, Košice 2006. ISBN 80-8073-533-6.

7. Riešenie konfliktov sa nezaobíde bez počúvania. In: eFocus, roč. 8, č. 1/08, s. 88-89. ISSN 1336-1805.

8. VIDOVÁ, J. - MIHOK, J.: Synergia vpodnikani ako spôsob predchádzania podnikovým krízam. In: Fórum manažéra, roč. II., č. 4/2006, Trnava 2006, s. 29-32. ISSN 1336-7773.

\section{Grantová podpora}

Príspevok bol pripravený v rámci riešenia grantovej úlohy VEGA 1/0052/08 Systémový prístup k racionalizácii pracovných procesov vo výrobných podnikoch. 